\title{
Influence of Steam Curing Method on the Performance of Concrete Containing a Large Portion of Mineral Admixtures
}

\author{
Mengyuan Li, Qiang Wang, and Jun Yang \\ Department of Civil Engineering, Tsinghua University, Beijing, China \\ Correspondence should be addressed to Qiang Wang; w-qiang@tsinghua.edu.cn
}

Received 24 February 2017; Accepted 29 March 2017; Published 24 April 2017

Academic Editor: Yao Luan

Copyright ( 2017 Mengyuan Li et al. This is an open access article distributed under the Creative Commons Attribution License, which permits unrestricted use, distribution, and reproduction in any medium, provided the original work is properly cited.

\begin{abstract}
A comparison was made between the impact of raising the thermostatic temperature and the impact of prolonging the thermostatic time on the performance of steam-cured concrete containing a large portion of fly ash (FA) or ground granulated blast furnace slag (GGBS) by analysing the form removal strength, chemically combined water content, reaction degree, strength development, chloride permeability, and volume stability. For the materials and test conditions reported in this study, raising the thermostatic temperature is more favourable for concrete containing FA, as indicated by the significantly higher form removal strength and the higher growth of reaction degree of FA compared with prolonging the thermostatic time. With an increase in the thermostatic temperature, the hydration degree of a binder containing FA or GGBS initially increases and subsequently decreases. Although concrete containing FA can obtain satisfactory form removal strength with steam curing at $80^{\circ} \mathrm{C}$, the late strength development of concrete containing FA is slow for the same curing conditions. The effect of the late performance of resistance to chloride ion permeability improved by FA is better than the effect improved by GGBS. The risk of destroying the structure of concrete containing a large portion of FA or GGBS due to delayed ettringite formation (DEF) is minimal when specimens were steam-cured at $80^{\circ} \mathrm{C}$.
\end{abstract}

\section{Introduction}

Concrete is one of the most common construction materials. Cast-in-situ concrete and precast concrete are two techniques that housing developers and construction workers often adopt. However, precast concrete members have been increasingly utilized in civil engineering construction in recent years due to their advantages: reliable quality assurance, simple production process, faster construction speed, and environmentally friendly building operations [1-3].

Currently available information indicates that the technique of steam curing is the most frequently employed technique among various production processes of prefabricated members $[4,5]$. The benefits of steam curing are as follows: simple process, convenient operation, production with high early strength, short production cycle, and superior economic benefits [5-7]. The steam curing process includes the following four stages: the precuring stage, the heating stage, the thermostatic stage, and the cooling stage $[8,9]$. The thermostatic temperature is generally less than $60^{\circ} \mathrm{C}$ during steam curing because of two reasons. Firstly, the growth of the late performance of concrete will be small if the thermostatic temperature is excessive during steam curing [10-12]. Secondly, the formation of ettringite produced by cement hydration in the case of a minimum curing temperature of $70^{\circ} \mathrm{C}$ is decomposed during steam curing and reformed during the service life. This process is called delayed ettringite formation (DEF), and it can substantially weaken the late performance of concrete [13-15].

Mineral admixtures are extensively applied in blended cement and concrete; this process is a substantial contribution to the field of civil engineering. The technology of steam curing has been primarily employed for pure cement concrete rather than concrete with a large portion of mineral admixtures as many researchers and housing developers have expressed their concern that the early compressive strength of concrete with a large portion of mineral admixtures is low [16-18], which make it difficult to satisfy the requirements of form removal strength of steam-cured concrete at the end of steam curing. This is an obstacle to the use of steam curing for concrete that incorporates a large portion of mineral admixtures. 
TABLE 1: Chemical compositions and specific surface areas of OPC, GGBS, and FA.

\begin{tabular}{lccc}
\hline & OPC & GGBS & FA \\
\hline $\mathrm{SiO}_{2}(\%)$ & 21.10 & 31.76 & 53.33 \\
$\mathrm{Al}_{2} \mathrm{O}_{3}(\%)$ & 6.33 & 14.84 & 27.65 \\
$\mathrm{Fe}_{2} \mathrm{O}_{3}(\%)$ & 4.22 & 0.60 & 6.04 \\
$\mathrm{CaO}(\%)$ & 54.86 & 36.44 & 2.86 \\
$\mathrm{MgO}(\%)$ & 2.60 & 9.08 & 1.35 \\
$\mathrm{SO}_{3}(\%)$ & 2.66 & 1.94 & 0.45 \\
$\mathrm{Na}_{2} \mathrm{O}_{\text {eq }}(\%)$ & 0.53 & 0.56 & 0.64 \\
Loss on ignition $(\%)$ & 2.42 & 0.86 & 4.71 \\
Specific surface area $\left(\mathrm{m}^{2} / \mathrm{kg}\right)$ & 376 & 430 & 358 \\
\hline
\end{tabular}

$\mathrm{Na}_{2} \mathrm{O}_{\text {eq }}=\mathrm{Na}_{2} \mathrm{O}+0.658 \mathrm{~K}_{2} \mathrm{O}$.

Although the early strength of concrete with a large portion of mineral admixtures is low at room temperature, high temperatures can promote the early hydration of a binder. By adjusting the thermostatic time and the thermostatic temperature under steam curing conditions, concrete with a large portion of mineral admixtures may achieve the required form removal strength. To address the problem of form removal strength and promote the high performance of steam-cured concrete that incorporates mineral admixtures, this paper addresses the influence of prolonging the thermostatic time and improving the thermostatic temperature on the form removal strength of concrete that incorporates a large portion of mineral admixtures. Our study also focused on a comparison between the impact of prolonging the thermostatic time and the impact of raising the thermostatic temperature on the hydration degree of a binder, the strength development and the resistance to the chloride ion permeability of concrete, and the volume stability of steam-cured concrete with a large portion of mineral admixtures.

\section{Raw Materials and Test Methods}

2.1. Raw Materials. P.O 42.5 ordinary Portland cement (OPC), ground granulated blast furnace slag (GGBS), and fly ash (FA) were employed in this study. The chemical compositions and specific surface areas of these powder materials are shown in Table 1. The fine aggregates consisted of natural river sands with particle sizes that ranged from 0.08 to $5 \mathrm{~mm}$. The coarse aggregates consisted of crushed limestone smaller than $25 \mathrm{~mm}$.

2.2. Test Methods. Table 2 exhibits the mix proportions of pastes that were used to measure the hydration property of a composite binder. Table 3 exhibits the mix proportions of concrete. Pastes in the plastic tube were prepared. Concrete samples with the dimensions of $10 \times 10 \times 10 \mathrm{~cm}^{3}$ were prepared for an experiment on compressive strength and the chloride ion permeability of concrete. Concrete samples with the dimensions of $10 \times 10 \times 300 \mathrm{~cm}^{3}$ were prepared for an experiment on volume stability of concrete.

The precuring time for steam curing was three hours $\left(20^{\circ} \mathrm{C}\right)$. The heating and cooling rate was $15 \pm 1^{\circ} \mathrm{C} / \mathrm{h}$. Eight
TABLE 2: Compositions of the pastes (\%).

\begin{tabular}{lcccc}
\hline Sample & OPC & $\begin{array}{c}\text { Binder } \\
\text { GGBS }\end{array}$ & FA & Water/binder ratio \\
\hline CC & 100 & 0 & 0 & 0.4 \\
FF & 60 & 0 & 40 & 0.4 \\
BB & 60 & 40 & 0 & 0.4 \\
\hline
\end{tabular}

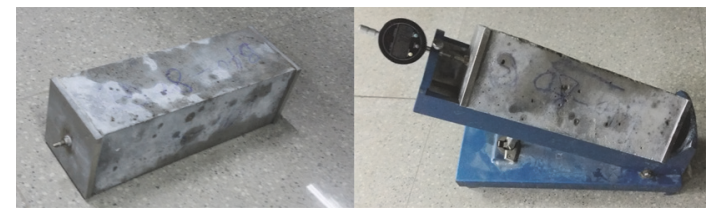

FIgURE 1: The measurement of volume stability of concrete.

thermostatic times were adopted: $8 \mathrm{~h}, 9 \mathrm{~h}, 10 \mathrm{~h}, 11 \mathrm{~h}, 12 \mathrm{~h}$, $13 \mathrm{~h}, 14 \mathrm{~h}$, and $16 \mathrm{~h}$. Four thermostatic temperatures were adopted: $60^{\circ} \mathrm{C}, 70^{\circ} \mathrm{C}, 80^{\circ} \mathrm{C}$, and $90^{\circ} \mathrm{C}$. Concrete that was used to measure the compressive strength and chloride ion permeability were cured at $20^{\circ} \mathrm{C}$ and a relative humidity greater than $95 \%$ after steam curing.

The chemically combined water $\left(w_{c}\right)$ content of hydration products was tested by the difference of weight between a sample dried at $80^{\circ} \mathrm{C}$ and a sample heated at $1060^{\circ} \mathrm{C}$, which were standardized by the weight after drying at $80^{\circ} \mathrm{C}$, and by subtracting the loss of ignition of the raw materials. The permeability of chloride ion of the concrete was obtained in accordance with ASTM C1202 "Standard Test Method for Electrical Indication of Concrete's Ability to Resist Chloride Ion Penetration." In order to control the quality of steamcured concrete, the deviation of strength was restricted to be less than $10 \%$. The determination of the degree of reaction of fly ash was based on a selective dissolution procedure using concentrated hydrochloric acid and water $[19,20]$. The determination of the degree of reaction of GGBS was based on a selective dissolution procedure using salicylic acidmethanol-acetone solution [21].

This study involves an experiment on the volume stability of concrete. Concrete that was used to measure volume stability was cured in a saturated $\mathrm{Ca}(\mathrm{OH})_{2}$ solution at $20^{\circ} \mathrm{C}$ after steam curing. As water is a necessity to DEF, the specimens after steam curing were placed in a saturated $\mathrm{Ca}(\mathrm{OH})_{2}$ solution to keep concrete completely wet during curing. This type of practice can prevent $\mathrm{Ca}(\mathrm{OH})_{2}$ dissolution and drying shrinkage. The consequence of the volume stability analysis was confirmed by measuring the lengths of the concrete specimens using a comparator at scheduled ages. Test probes were installed in advance on both ends of the concrete specimens. Concrete that was used to measure volume stability and the process of measuring volume stability are shown in Figure 1.

\section{Results and Discussion}

3.1. Form Removal Strength of Concrete. The influence of thermostatic time and thermostatic temperature on the form removal strength of steam-cured concrete is presented in 
TABLE 3: Mix proportions of the concrete $\left(\mathrm{kg} / \mathrm{m}^{3}\right)$.

\begin{tabular}{lcccccc}
\hline Sample & OPC & GGBS & FA & Fine aggregates & Coarse aggregates & Water \\
\hline C & 350 & 0 & 0 & 812 & 1077 & 1077 \\
F30 & 245 & 0 & 105 & 140 & 812 & 1077 \\
F40 & 210 & 0 & 175 & 812 & 1077 & 161 \\
F50 & 175 & 0 & 0 & 812 & 1077 & 161 \\
B30 & 245 & 105 & 0 & 812 & 1077 & 161 \\
B40 & 210 & 140 & 0 & 812 & 1077 & 161 \\
B50 & 175 & 175 & 0 & 812 & 1077 \\
B60 & 140 & 210 & & & 161 \\
\hline
\end{tabular}

TABLE 4: Removal strengths under different curing conditions.

\begin{tabular}{lccc}
\hline Samples & Thermostatic temperature $/{ }^{\circ} \mathrm{C}$ & Thermostatic time/h & Removal strength/MPa \\
\hline C & 60 & 9 & 28.7 \\
F30 & 60 & 11 & 23.7 \\
& 80 & 9 & 35.7 \\
F40 & 60 & 11 & 17.7 \\
& 80 & 9 & 29.7 \\
F50 & 60 & 13 & 10.4 \\
& 80 & 11 & 26.8 \\
B30 & 60 & 11 & 27.8 \\
& 80 & 9 & 31.0 \\
B40 & 60 & 11 & 32.7 \\
B50 & 80 & 9 & 27.2 \\
& 60 & 11 & 20.0 \\
B60 & 80 & 9 & 22.6 \\
\end{tabular}

Table 4. The form removal strength of pure cement concrete that is cured at $60^{\circ} \mathrm{C}$ for $9 \mathrm{~h}$ in steam curing is established as the control group. When a thermostatic temperature of $60^{\circ} \mathrm{C}$ is maintained, the form removal strength of concrete F30 (thermostatic time: $11 \mathrm{~h}$ ), F40 (thermostatic time: $11 \mathrm{~h}$ ), and F50 (thermostatic time: $13 \mathrm{~h}$ ) is lower than the form removal strength of the control group. When a thermostatic temperature of $80^{\circ} \mathrm{C}$ is maintained, the form removal strength of concrete F30 and F40 (thermostatic time: $9 \mathrm{~h}$ ) is higher than the form removal strength of the control group. When the thermostatic temperature is increased to $80^{\circ} \mathrm{C}$ and the thermostatic time is simultaneously prolonged to $11 \mathrm{~h}$, the form removal strength of concrete F50 is also similar to the form removal strength of the control group. It is an indication that the degree of influence of raising the thermostatic temperature on the form removal strength of concrete containing FA is superior to the degree of influence of prolonging the thermostatic time on the form removal strength of concrete containing FA. Raising the thermostatic temperature to $80^{\circ} \mathrm{C}$ can attain satisfactory form removal strength.

By utilizing the form removal strength of pure cement concrete under steam curing at $60^{\circ} \mathrm{C}$ for $9 \mathrm{~h}$ as the reference, the form removal strength of concrete B30 and B40 cured at $80^{\circ} \mathrm{C}$ for $9 \mathrm{~h}$ is similar to the form removal strength of the control group. The form removal strength of concrete B50 that was cured at $80^{\circ} \mathrm{C}$ for $9 \mathrm{~h}$ is obviously lower than the form removal strength of the control group. However, by prolonging the thermostatic time to $10 \mathrm{~h}$, the form removal strength of concrete $\mathrm{B} 60$ that was cured at $80^{\circ} \mathrm{C}$ is similar to the form removal strength of the control group. By prolonging the thermostatic time to $11 \mathrm{~h}$ and controlling the thermostatic temperature $\left(60^{\circ} \mathrm{C}\right)$ as a constant, the form removal strengths of concrete $\mathrm{B} 30$ and $\mathrm{B} 40$ are similar to the form removal strength of the control group and the form removal strengths of concrete B50 and B60 are lower than the form removal strength of the control group. Both raising the thermostatic temperature and prolonging the thermostatic time enhance the form removal strength of concrete that incorporates a large portion of GGBS. When the content of GGBS in cementing materials exceeds $50 \%$, methods of prolonging the thermostatic time and raising the thermostatic temperature need to be simultaneously employed to obtain the satisfactory form removal strength as the influence of prolonging the thermostatic time on enhancing the form removal strength is limited.

3.2. Chemically Combined Water Content. $w_{c}$ content of hydration products reveals the hydration degree of the same binder. The influences of the thermostatic time on $w_{c}$ content of cement paste, the paste containing a large portion of GGBS, 


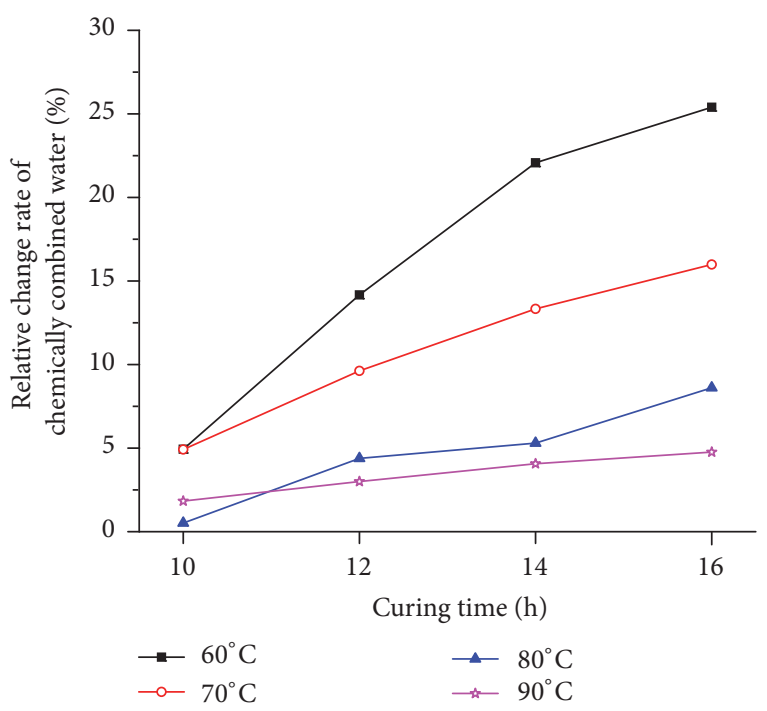

(a) Sample CC

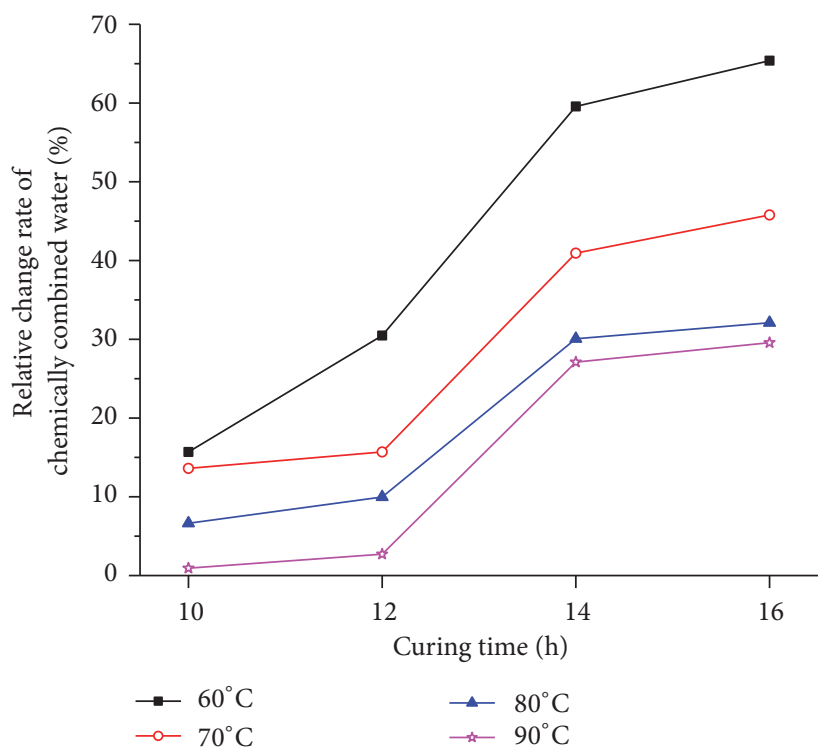

(b) Sample BB

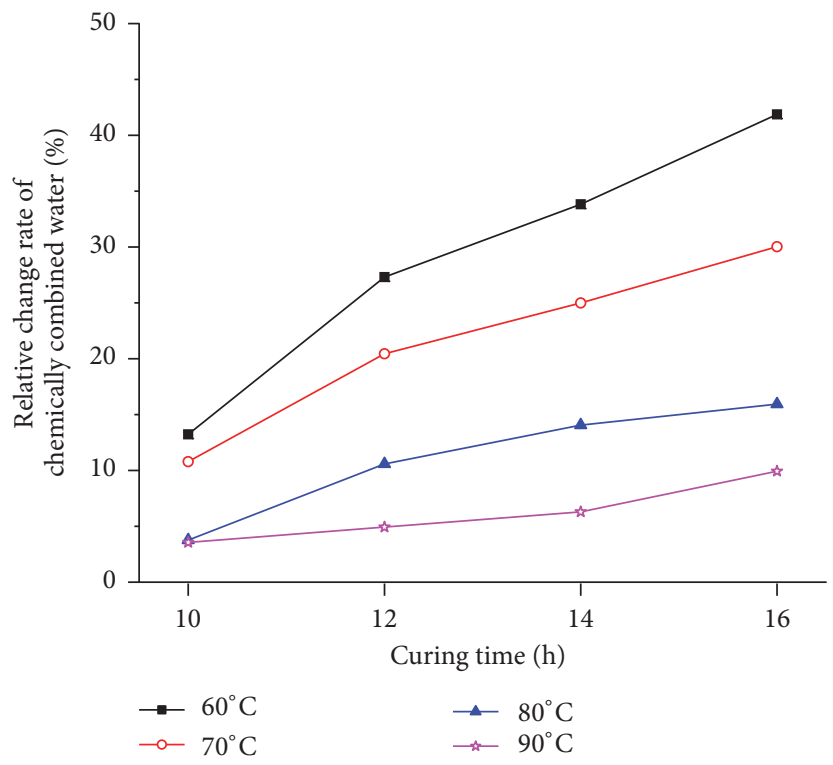

(c) Sample FF

FIGURE 2: The influence of thermostatic time on $w_{c}$ content.

and the paste containing a large portion of FA are illustrated in Figures 2(a), 2(b), and 2(c), respectively, at the end of the steam curing process. The ordinates in Figure 2 denote the relative change rate of $w_{c}$ content of pastes that were cured for $10 \mathrm{~h}, 12 \mathrm{~h}, 14 \mathrm{~h}$, and $16 \mathrm{~h}$ relative to the paste cured for $8 \mathrm{~h}$.

Figure 2(a) indicates that $w_{c}$ content of pure cement paste increases with an increase in thermostatic time; however, if the curing temperature in the thermostatic period is low, the growth rate of $w_{c}$ content is high with the extension of thermostatic time. This finding may be attributable to this reason: $8 \mathrm{~h}$ of curing in the thermostatic period is sufficient for the hydration degree of cement achieving a high level when the temperature in the thermostatic period is sufficiently high. Few contributions to improving the hydration degree of cement have been achieved by prolonging the thermostatic time under this circumstance.

Conclusions can be drawn from Figures 2(b) and 2(c). (1) When the curing temperature in the thermostatic period is low, the growth rates of $w_{c}$ content of the binder with a large portion of GGBS and the binder with a large portion of FA are high due to the extension of thermostatic time, which is similar to the pure cement paste. (2) The order of the degree of influence of prolonging the thermostatic time on improving $w_{c}$ content of binders is the binder containing large portion mineral admixtures $>$ the pure cement paste at the same thermostatic temperature. This finding may be attributable to this reason: when considering the binder containing a large portion of GGBS or FA, the thermostatic time may 


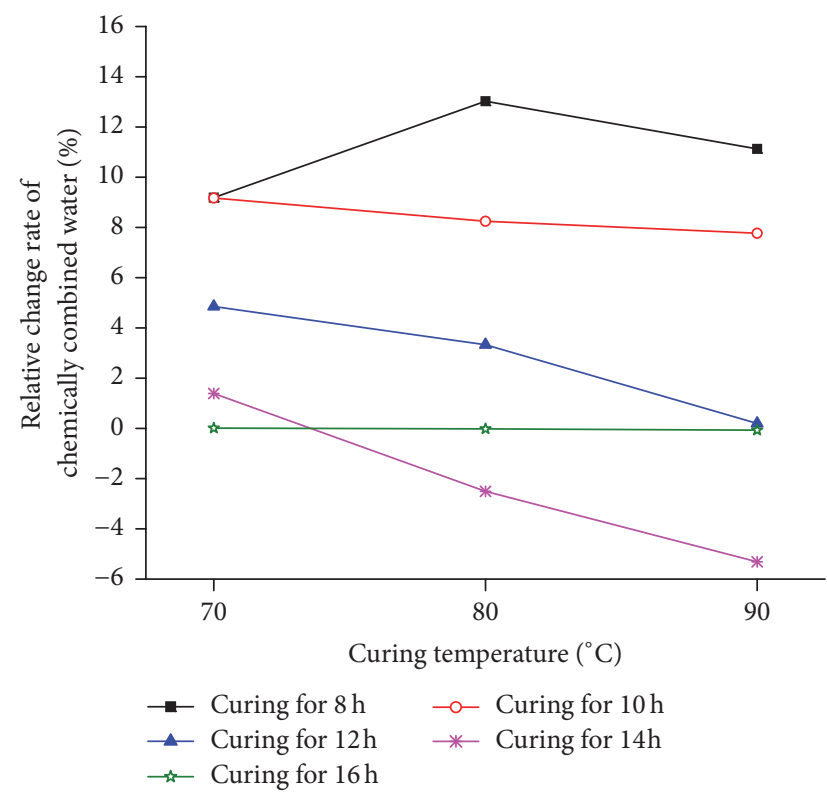

(a) Sample CC

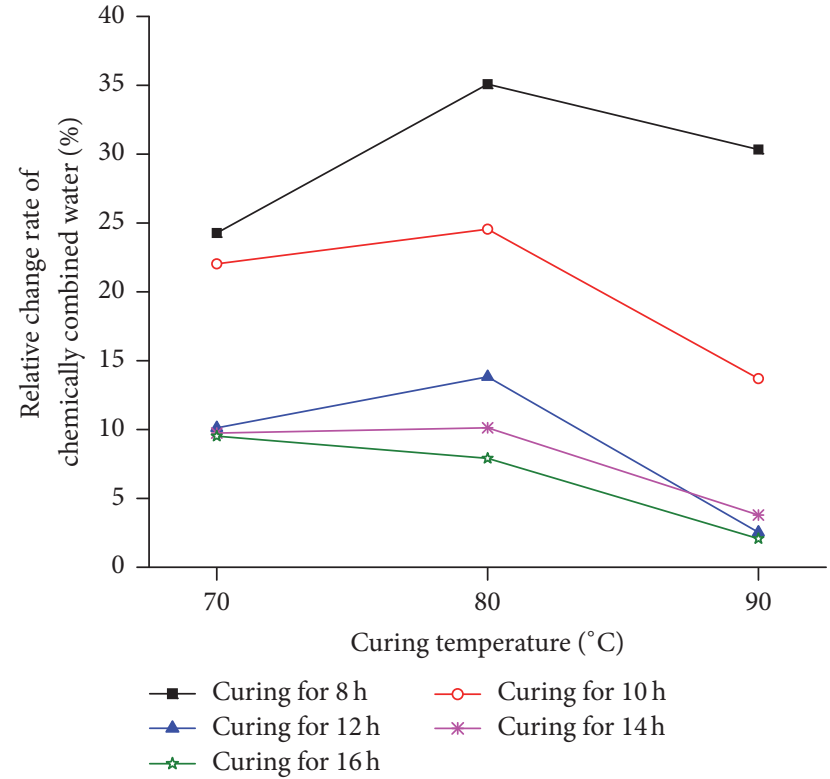

(b) Sample BB

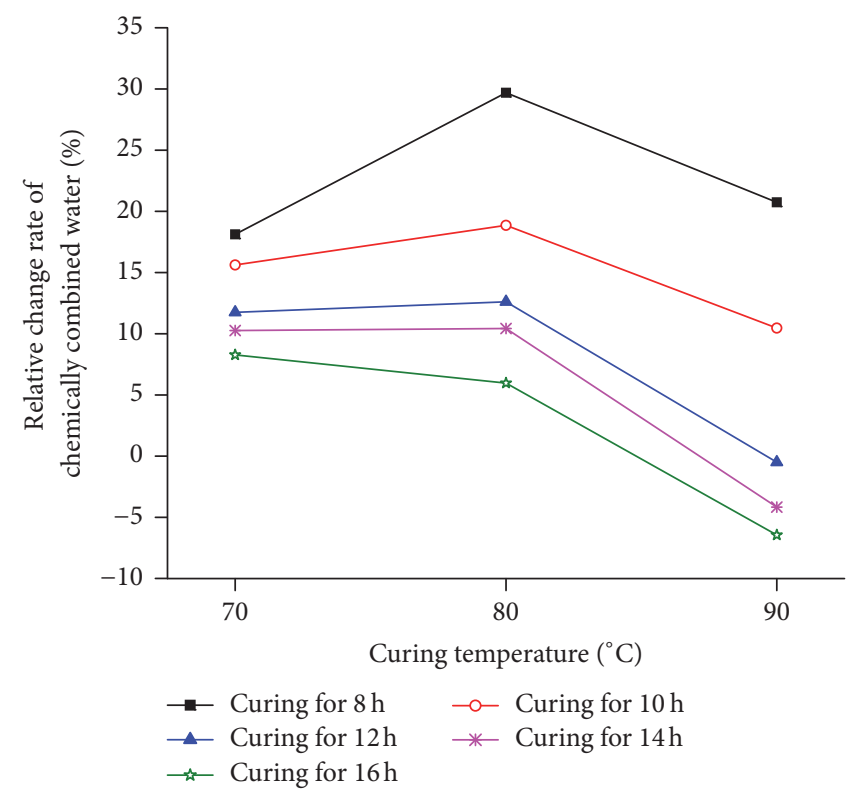

(c) Sample FF

FIGURE 3: The influence of thermostatic temperature on $w_{c}$ content.

improve not only the hydration reaction of cement but also the reaction of GGBS or FA. (3) The order of the degrees of influence of prolonging the thermostatic time on improving $w_{c}$ content of binders is the binder containing a large portion of GGBS > the binder containing a large portion of FA. The order of the degree of influence of the thermostatic time on the hydration degree is the binder containing a large portion of GGBS > the binder containing a large portion of FA. This finding is consistent with the trend for the form removal strength that is presented in Table 4.

The influence of the thermostatic temperature on $w_{c}$ content of cement paste, the paste containing a large portion of GGBS, and the paste containing a large portion of FA at the end of the steam curing process is illustrated in Figures 3(a), 3(b), and 3(c), respectively. The ordinates in Figure 3 denote the relative change rate of $w_{c}$ content of pastes cured at $70^{\circ} \mathrm{C}, 80^{\circ} \mathrm{C}$, and $90^{\circ} \mathrm{C}$ relative to the paste cured at $60^{\circ} \mathrm{C}$. A positive relative change rate indicates that an increase in the thermostatic temperature from $60^{\circ} \mathrm{C}$ can further enhance the hydration of binder. A negative relative change rate indicates that an increase in the thermostatic temperature from $60^{\circ} \mathrm{C}$ would inhibit the hydration of binder.

Figure $3(\mathrm{a})$ reveals that $w_{c}$ content of the hydration products of cement has not always increased with an increase 
TABLE 5: Reaction degree of fly ash and GGBS/\%.

\begin{tabular}{lcccc}
\hline & \multicolumn{2}{c}{ Thermostatic time $/$ h } \\
& Thermostatic temperature $/{ }^{\circ} \mathrm{C}$ & 8 & \multicolumn{2}{c}{12} \\
\hline \multirow{2}{*}{ Fly ash } & 60 & 2.11 & 4.26 & 6.39 \\
& 80 & 5.79 & 7.96 & 9.73 \\
\multirow{2}{*}{ GGBS } & 60 & 7.86 & 10.15 & 13.18 \\
& 80 & 9.84 & 13.15 & 15.25 \\
\hline
\end{tabular}

in the thermostatic temperature. When the thermostatic time is $8 \mathrm{~h}, 10 \mathrm{~h}, 12 \mathrm{~h}$, and $14 \mathrm{~h}, w_{c}$ content initially increases and subsequently decreases with an increase in thermostatic temperature. When the thermostatic time is $16 \mathrm{~h}, w_{c}$ content remains unchanged with an increase in the thermostatic temperature. Therefore, when the thermostatic period is short, an increase in the thermostatic temperature from $60^{\circ} \mathrm{C}$ to $70^{\circ} \mathrm{C}$ can enhance the hydration degree of pure cement paste. For a long thermostatic period, an increase in the thermostatic temperature is not needed to enhance the hydration degree of pure cement paste.

Conclusions can be drawn from Figures 3(b) and 3(c): (1) when the thermostatic temperature increases from $60^{\circ} \mathrm{C}$ to $70^{\circ} \mathrm{C}, w_{c}$ content of every group increases; (2) when the thermostatic temperature increases from $70^{\circ} \mathrm{C}$ to $80^{\circ} \mathrm{C}, w_{c}$ content of the pastes, which have thermostatic times of $8 \mathrm{~h}$, $10 \mathrm{~h}$, and $12 \mathrm{~h}$, increases, and $w_{c}$ content of the pastes, which have a thermostatic time of $14 \mathrm{~h}$ and $16 \mathrm{~h}$, remains unchanged or slightly decreased; (3) when the thermostatic temperature increases from $80^{\circ} \mathrm{C}$ to $90^{\circ} \mathrm{C}, w_{c}$ content of every group decreases. Note that the change rate of $w_{c}$ content of the paste containing a large portion of FA (thermostatic period: $90^{\circ} \mathrm{C} / 14 \mathrm{~h}$ or $16 \mathrm{~h}$ ) relative to the change rate of the paste cured at $60^{\circ} \mathrm{C}$ is negative.

This result indicates that increasing the thermostatic temperature to $80^{\circ} \mathrm{C}$ can effectively enhance the hydration degree of paste containing a large portion of FA or GGBS. Compared with Figure 3(a), by increasing the thermostatic temperature, the hydration promoting effect of paste containing a large portion of FA or GGBS is more apparent than the hydration promoting effect of pure cement paste. This finding may be attributable to two reasons: firstly, increasing the thermostatic temperature not only improves the hydration reaction of cement but also stimulates the activity of FA or GGBS; secondly, the reaction degree of fly ash and GGBS is much lower than that of cement at normal temperature.

3.3. The Reaction Degree of Mineral Admixtures. The influence of the thermostatic time on the reaction degree of GGBS and FA is presented in Table 5. Regardless of whether the thermostatic temperature is $60^{\circ} \mathrm{C}$ or $80^{\circ} \mathrm{C}$, the reaction degree of GGBS or FA will increase with an extension of the thermostatic time. This result may be attributed to this reason: the longer is the thermostatic time, the longer is the time required to stimulate the activity of GGBS or FA, which will increase the reaction degree of GGBS or FA.

Table 5 also reveals that the reaction degree of FA (thermostatic period: $60^{\circ} \mathrm{C} / 8 \mathrm{~h}$ ) is only $2.1 \%$, which demonstrates that FA only serves a role in the microaggregate filling effect in this situation. The reaction degree of FA (thermostatic period: $60^{\circ} \mathrm{C} / 16 \mathrm{~h}$ ) is $6.4 \%$, which is substantially higher than the reaction degree of $\mathrm{FA}$ after $8 \mathrm{~h}$ of curing during the thermostatic period. However, the reaction degree remains at a low level from the point of absolute value. Therefore, prolonging the thermostatic time at $60^{\circ} \mathrm{C}$ is not an effective way for the concrete containing a large portion of FA to achieve a satisfactory form removal strength. Conversely, the reaction degree of GGBS at $60^{\circ} \mathrm{C}$ for $8 \mathrm{~h}$ is $7.9 \%$, which even exceeds the reaction degree of FA at $60^{\circ} \mathrm{C}$ for $16 \mathrm{~h}$. The absolute value of the reaction degree of GGBS is obviously higher than that of the reaction degree of FA in an equivalent steam curing system, which suggests that the chemical effect of GGBS is obviously higher than the chemical effect of FA in the early steam curing process.

The following can also be concluded from Table 5. (1) When the thermostatic temperature increases from $60^{\circ} \mathrm{C}$ to $80^{\circ} \mathrm{C}$, the reaction degree of GGBS and FA is improved. (2) The influence of increasing the thermostatic temperature on the reaction degree of FA is more significant from the point of growth.

From the perspective of the reaction degree of mineral admixtures as well as the hydration degree of the whole binder, it is obvious that the promoting effect of increasing the thermostatic temperature is more significant than the promoting effect of prolonging the thermostatic time on the early hydration of the binder containing a large portion of FA. Increasing the thermostatic temperature and prolonging the thermostatic time have a significant role in promoting the hydration of GGBS. This case also applies to the influence of the thermostatic temperature and thermostatic time on the form removal strength of concrete.

3.4. Strength Development of Concrete. The comparison between the strength development of pure cement concrete after steam curing and the strength development of steamcured concrete containing a large portion of GGBS and FA is shown in Figure 4. The strength development of pure cement concrete (thermostatic period: $60^{\circ} \mathrm{C} / 9 \mathrm{~h}$ ) is employed as the reference. Figure 4(a) shows the strength development of concrete containing FA after steam curing at $80^{\circ} \mathrm{C}$. As shown in Figure 4(a), although the form removal strength of steam-cured concrete containing a large portion of FA is not lower than the form removal strength of the control group, the compressive strength of steam-cured concrete containing a large portion of FA is substantially lower than the form removal strength of the control group at the age of 28 days 


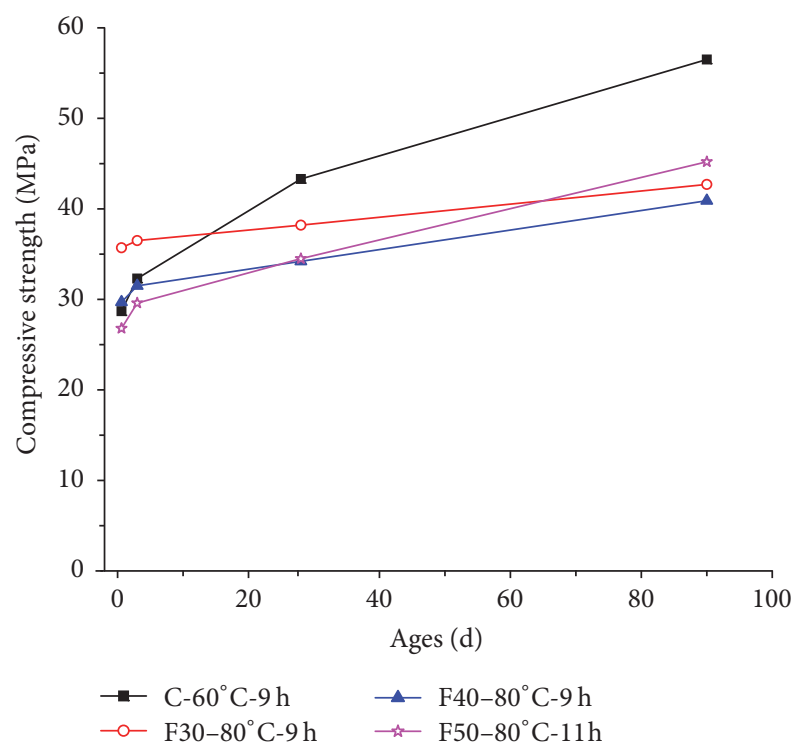

(a) Concrete containing FA at $80^{\circ} \mathrm{C}$

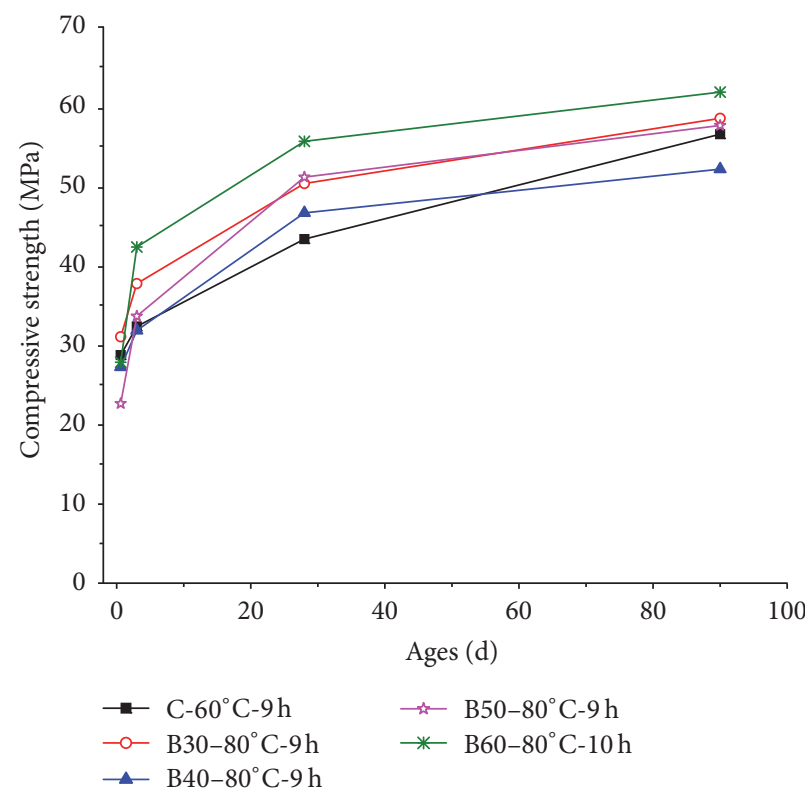

(c) Concrete containing GGBS at $80^{\circ} \mathrm{C}$

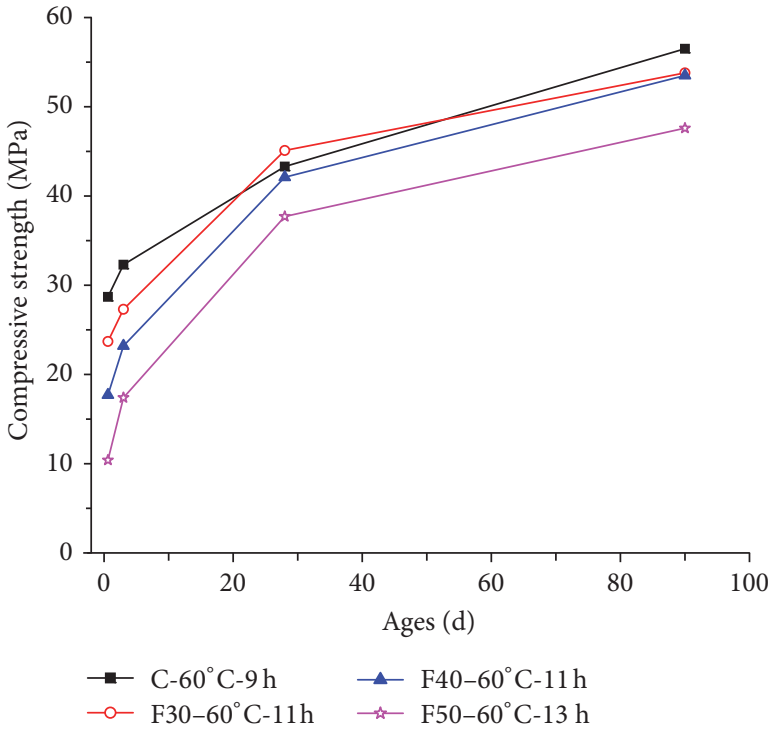

(b) Concrete containing $\mathrm{FA}$ at $60^{\circ} \mathrm{C}$

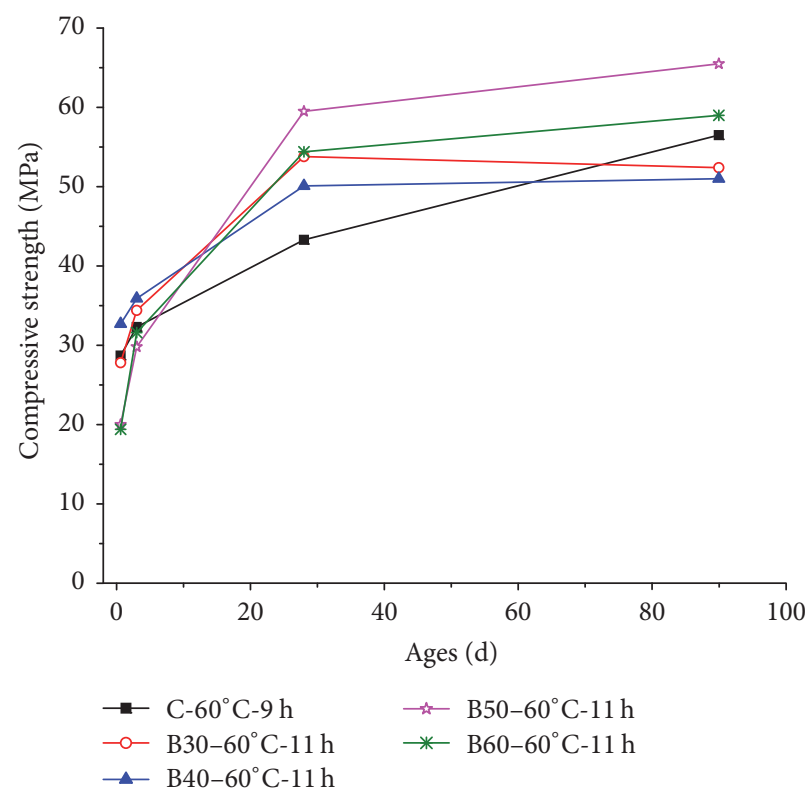

(d) Concrete containing GGBS at $60^{\circ} \mathrm{C}$

FIGURE 4: Comparison of strength development between pure cement concrete and concrete containing large portion FA or GGBS under steam curing.

and 90 days. After the age of three days, the strength growth of steam-cured concrete containing a large portion of FA is very slow, which differs from the strength growth of ordinary concrete containing FA [22-24]. The greater the content of FA, the greater the contribution of the pozzolanic reaction to the strength at a later age, and the greater the potential for subsequent growth of concrete. High temperatures enhance the form removal strength of concrete containing FA at an early age; however, it hinders the strength development of concrete at a later age. Possible reasons for this phenomenon are as follows. (1) When the thermostatic temperature is $80^{\circ} \mathrm{C}$, the early reaction of cement is significant. The gel layer of
C-S-H can be formed in the particles' surfaces of cement and FA, which is disadvantage for further hydration of binder at a later age. (2) The distribution of the hydration product of cement is uneven at elevated temperatures, and a large amount of $\mathrm{Ca}(\mathrm{OH})_{2}$ crystal exhibits orientation distribution. Thus, the contact area between FA and $\mathrm{Ca}(\mathrm{OH})_{2}$ is reduced. The pozzolanic reaction of FA at a later age is restricted.

Figure 4(b) shows the strength development of concrete containing FA after steam curing at $60^{\circ} \mathrm{C}$. As shown in Figure 4(b), although the growth rate of the late strength of concrete containing FA is similar to the growth rate of the control group, the form removal of concrete containing FA 
TABLE 6: Chloride ion permeability of concrete.

\begin{tabular}{|c|c|c|c|c|c|c|}
\hline \multirow[b]{2}{*}{ Samples } & \multirow[b]{2}{*}{$\begin{array}{l}\text { Thermostatic } \\
\text { temperature } /{ }^{\circ} \mathrm{C}\end{array}$} & \multirow[b]{2}{*}{$\begin{array}{l}\text { Thermostatic } \\
\text { time/h }\end{array}$} & \multicolumn{2}{|c|}{$28 \mathrm{~d}$} & \multicolumn{2}{|c|}{$90 \mathrm{~d}$} \\
\hline & & & $\begin{array}{c}\text { Charge } \\
\text { passed/C }\end{array}$ & $\begin{array}{c}\text { Permeability } \\
\text { level }\end{array}$ & $\begin{array}{c}\text { Charge } \\
\text { passed/C }\end{array}$ & $\begin{array}{c}\text { Permeability } \\
\text { level }\end{array}$ \\
\hline $\mathrm{C}$ & 60 & 9 & 7111 & High & 4338 & High \\
\hline \multirow{2}{*}{ F30 } & 60 & 11 & 1714 & Low & 700 & Very low \\
\hline & 80 & 9 & 644 & Very low & 503 & Very low \\
\hline \multirow{2}{*}{ F40 } & 60 & 11 & 1707 & Low & 510 & Very low \\
\hline & 80 & 9 & 682 & Very low & 278 & Very low \\
\hline \multirow{2}{*}{ F50 } & 60 & 13 & 1952 & Low & 607 & Very low \\
\hline & 80 & 11 & 518 & Very low & 200 & Very low \\
\hline \multirow{2}{*}{ B30 } & 60 & 11 & 2094 & Moderate & 1350 & Low \\
\hline & 80 & 9 & 2628 & Moderate & 1709 & Low \\
\hline \multirow{2}{*}{ B40 } & 60 & 11 & 2424 & Moderate & 1535 & Low \\
\hline & 80 & 9 & 2765 & Moderate & 1650 & Low \\
\hline \multirow{2}{*}{ B50 } & 60 & 11 & 1668 & Low & 1117 & Low \\
\hline & 80 & 9 & 2075 & Moderate & 1213 & Low \\
\hline \multirow{2}{*}{ B60 } & 60 & 11 & 1515 & Low & 813 & Very low \\
\hline & 80 & 10 & 1150 & Low & 775 & Very low \\
\hline
\end{tabular}

is lower than the growth rate of the control group, especially for the larger content of FA of concrete. At a thermostatic temperature of $60^{\circ} \mathrm{C}$, the form removal strength of concrete containing $\mathrm{FA}$ is relatively low, which explains why the stimulation degree of $60^{\circ} \mathrm{C}$ for the early activity of the binder containing a large portion of FA is limited.

Figures 4(c) and 4(d) show the strength development of concrete containing GGBS after steam curing at $60^{\circ} \mathrm{C}$ and $80^{\circ} \mathrm{C}$, respectively. Regardless of whether the thermostatic time is prolonged or the thermostatic temperature is increased, the early strength and the strength growth rate at a later age of concrete that contain a large portion of GGBS are similar to the early strength and the strength growth rate of the control group. Therefore, at high temperatures, the effect of GGBS exceeds the effect of FA in the process of the formation of the concrete strength: first, at $60^{\circ} \mathrm{C}$, GGBS exhibits a relatively high activity at an early age and it substantially contributes to the form removal strength and early strength; second, GGBS can display substantial early activity at $80^{\circ} \mathrm{C}$; third, even if the concrete containing a large portion of GGBS is cured at $80^{\circ} \mathrm{C}$, it can obtain a satisfactory late strength. This finding suggests that GGBS serves an important role in the late strength growth of steam-cured concrete; that is, after steam curing at a high temperature, GGBS can still take a considerable pozzolanic reaction at a high reaction rate at a later age.

3.5. Resistance to Chloride Ion Permeability of Concrete. The comparison between chloride ion permeability of concrete containing a large portion of FA or GGBS and the chloride ion permeability of pure cement concrete after steam curing is illustrated in Table 6 . The chloride ion permeability of pure cement concrete (thermostatic period: $60^{\circ} \mathrm{C} / 9 \mathrm{~h}$ ) at the same age is employed as the reference. According to ASTM $\mathrm{C1202}$, which is related to the chloride ion permeability grade classification, the permeability of the control group at $28 \mathrm{~d}$ falls in the "High" level, the permeability of concrete containing FA which is cured at $80^{\circ} \mathrm{C}$ falls in the "Very Low" level, and the permeability of concrete containing FA which is cured at $60^{\circ} \mathrm{C}$ falls in the "Low" level. At the age of 90 days, the permeability of the control group falls in the "High" level, and the permeability of concrete containing FA which is cured at $60^{\circ} \mathrm{C}$ and $80^{\circ} \mathrm{C}$ falls in the "Very Low" level. This finding suggests that the resistance to chloride ion permeability of steam-cured concrete containing FA is substantially better than the resistance of pure cement concrete, which is one of the advantages to steam-cured concrete containing a large portion of FA. FA can enhance the resistance to chloride ion permeability of concrete at a later age, which has been confirmed by a large number of experiments [25]. The main reason for this improvement is the ability of FA to improve on the pore structure of concrete due to pozzolanic reaction [26]; the secondary hydration products decrease the connected porosity of concrete. Therefore, the higher is the reaction degree of FA, the greater is the contribution to the resistance to the chloride ion permeability of concrete. High temperature curing at an early age can significantly stimulate the activity of FA and enhance the reaction degree of FA. Thus, FA enhances the resistance of steam-cured concrete to chloride ion permeability.

At the age of 28 days, the permeability of steam-cured concrete containing GGBS falls in the "Moderate" or "Low" levels. At the age of 90 days, the permeability of steamcured concrete containing GGBS falls in the "Low" or "Very Low" levels. The greater is the mixing amount of GGBS, the better is the resistance to the chloride ion permeability of concrete. Compared with pure cement concrete, the concrete containing GGBS can achieve better resistance to chloride ion permeability. In addition, the chloride ion permeability of steam-cured concrete containing GGBS of each group 


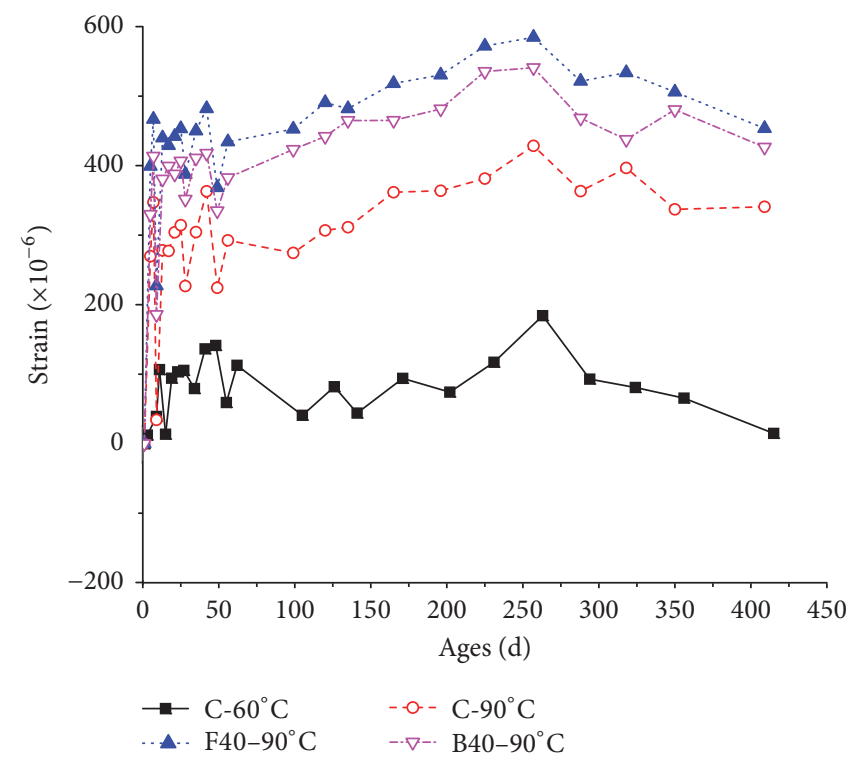

(a) Cured at $90^{\circ} \mathrm{C}$

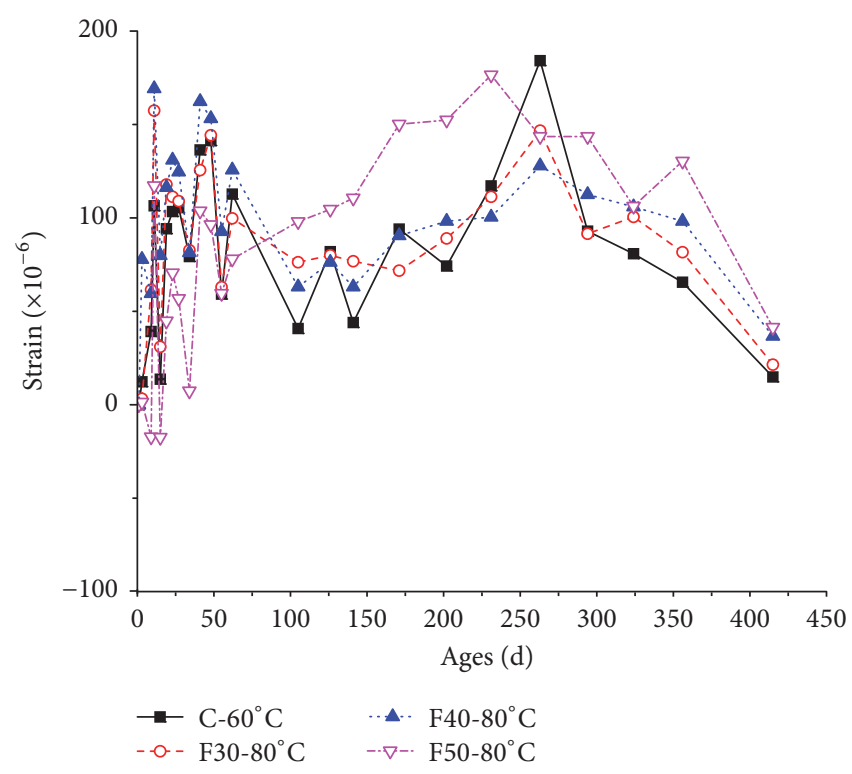

(b) Concrete containing FA at $80^{\circ} \mathrm{C}$

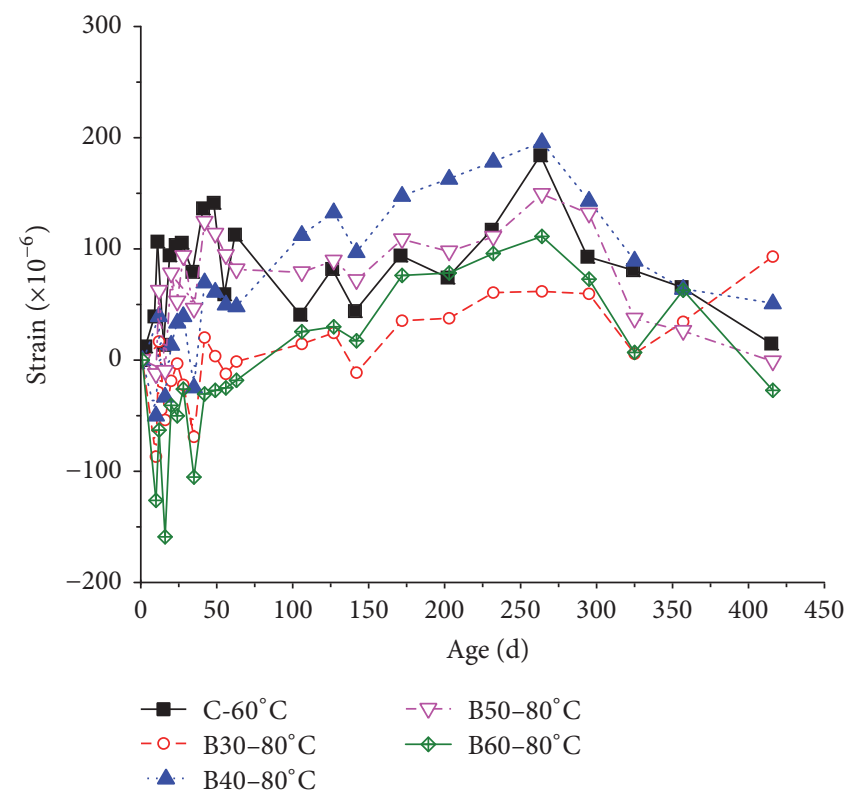

(c) Concrete containing GGBS at $80^{\circ} \mathrm{C}$

Figure 5: Volume deformation of steam-cured concrete.

is not substantially different due to the difference in the curing systems, as both prolonging the thermostatic time and improving the thermostatic temperature can stimulate the reaction activity of GGBS and substantially improve the pore structure of concrete. The effect of the late performance of resistance to chloride ion permeability improved by FA is better than the effect by GGBS. Although the reaction degree of GGBS is higher than the reaction degree of FA after steam curing, the pozzolanic reaction of FA can consume a mass of $\mathrm{Ca}(\mathrm{OH})_{2}$. The amount of $\mathrm{Ca}(\mathrm{OH})_{2}$ consumed by GGBS is minimal. Therefore, the reaction of FA plays a significant role in improving the pore structure of concrete.
3.6. Volume Stability Analysis of Concrete. The comparison between the volume deformation of steam-cured concrete containing a large portion of FA or GGBS and the volume deformation of pure cement concrete after steam curing is presented in Figure 5. Figure 5(a) shows the comparison between the volume deformation of concrete containing a large portion of FA or GGBS, the volume deformation of pure cement concrete with steam curing at $90^{\circ} \mathrm{C}$, and the volume deformation of pure cement concrete with steam curing at $60^{\circ} \mathrm{C}$. The microstrain of pure cement concrete (thermostatic period: $60^{\circ} \mathrm{C} / 8 \mathrm{~h}$ ) is employed as the reference. For steam curing at $90^{\circ} \mathrm{C}$, the inflation rates for the cement concrete and 
the concrete containing a large portion of FA or GGBS are relatively high, of which the late microstrain varies from 200 to 600 . However, the late microstrain of the control group is less than 200. These results indicate that the inflation rates of the cement concrete and the concrete containing a large portion of FA or GGBS are substantially higher than the inflation rates of the control group. A large number of studies have proven that DEF cannot weaken the late performance of concrete at thermostatic temperatures below $60^{\circ} \mathrm{C}$. Thus, the inflation rate of the control group can be considered to be a safe value. Conversely, the possibility of the structure of the cement concrete and the concrete containing a large portion of FA or GGBS destroyed by DEF after steam curing at $90^{\circ} \mathrm{C}$ is significant.

The volume deformation of steam-cured concrete containing a large portion of FA and GGBS with steam curing at $80^{\circ} \mathrm{C}$ is illustrated in Figures 5(b) and 5(c), respectively. All the concrete types produce normal strain with a certain degree at a later age. The strains of steam-cured concrete containing a large portion of FA or GGBS at $80^{\circ} \mathrm{C}$ are similar to the strains of the control group. Therefore, the risk of destroying the structure of concrete containing a large portion of FA or GGBS due to DEF when specimens were steam-cured at $80^{\circ} \mathrm{C}$ is minimal.

\section{Conclusions}

(1) Improving the thermostatic temperature is more favourable for concrete containing FA, as indicated by the significantly higher form removal strength and higher growth of reaction degree of FA compared with the method of prolonging the thermostatic time. Both improving the thermostatic temperature and prolonging the thermostatic time contribute to a distinct enhancement of the form removal strength of concrete that incorporates a large portion of GGBS and the reaction degree of GGBS.

(2) With an increase in the thermostatic temperature from $60^{\circ} \mathrm{C}$ to $90^{\circ} \mathrm{C}$, the hydration degree of binder containing FA or GGBS initially increases and subsequently decreases.

(3) Concrete containing FA can obtain satisfactory form removal strength with steam curing at $80^{\circ} \mathrm{C}$; however, the late strength growth rate of concrete containing $\mathrm{FA}$ is low for the same curing conditions.

(4) The effect of late performance of resistance to chloride ion permeability improved by FA is better than the same effect achieved by GGBS.

(5) The risk of destroying the structure of concrete containing FA or GGBS due to DEF when specimens were steam-cured at $80^{\circ} \mathrm{C}$ is minimal.

\section{Conflicts of Interest}

The authors declare that they have no conflicts of interest.

\section{Acknowledgments}

The authors would like to acknowledge National Natural Science Foundation of China (no. 51478248) and the Tsinghua University Initiative Scientific Research Program (20131089239).

\section{References}

[1] Z.-M. He, G.-C. Long, and Y.-J. Xie, "Influence of subsequent curing on water sorptivity and pore structure of steam-cured concrete," Journal of Central South University of Technology (English Edition), vol. 19, no. 4, pp. 1155-1162, 2012.

[2] H.-K. Choi, Y.-C. Choi, and C.-S. Choi, "Development and testing of precast concrete beam-to-column connections," Engineering Structures, vol. 56, pp. 1820-1835, 2013.

[3] H. B. Jiang, Q. Cao, A. R. Liu, T. L. Wang, and Y. Qiu, "Flexural behavior of precast concrete segmental beams with hybrid tendons and dry joints," Construction and Building Materials, vol. 110, pp. 1-7, 2016.

[4] Z. M. He, J. Z. Liu, and K. W. Zhu, "Influence of mineral admixtures on the short and long-term performance of steamcured concrete," Energy Procedia, vol. 16, pp. 836-841, 2012.

[5] G. Long, Z. He, and A. Omran, "Heat damage of steam curing on the surface layer of concrete," Magazine of Concrete Research, vol. 64, no. 11, pp. 995-1004, 2012.

[6] A. M. Ramezanianpour, K. Esmaeili, S. A. Ghahari, and A. A. Ramezanianpour, "Influence of initial steam curing and different types of mineral additives on mechanical and durability properties of self-compacting concrete," Construction and Building Materials, vol. 73, pp. 187-194, 2014.

[7] J. L. García Calvo, M. C. Alonso, L. Fernández Luco, and M. Robles Velasco, "Durability performance of sustainable self compacting concretes in precast products due to heat curing," Construction and Building Materials, vol. 111, pp. 379-385, 2016.

[8] I. Won, Y. Na, J. T. Kim, and S. Kim, "Energy-efficient algorithms of the steam curing for the in situ production of precast concrete members," Energy and Buildings, vol. 64, pp. 275-284, 2013.

[9] F. Cassagnabère, G. Escadeillas, and M. Mouret, "Study of the reactivity of cement/metakaolin binders at early age for specific use in steam-cured precast concrete," Construction and Building Materials, vol. 23, no. 2, pp. 775-784, 2009.

[10] G. Long, M. Wang, Y. Xie, and K. Ma, "Experimental investigation on dynamic mechanical characteristics and microstructure of steam-cured concrete," Science China Technological Sciences, vol. 57, no. 10, pp. 1902-1908, 2014.

[11] S. J. Barnett, M. N. Soutsos, S. G. Millard, and J. H. Bungey, "Strength development of mortars containing ground granulated blast-furnace slag: effect of curing temperature and determination of apparent activation energies," Cement and Concrete Research, vol. 36, no. 3, pp. 434-440, 2006.

[12] M. Paul and F. P. Glasser, "Impact of prolonged warm $\left(85^{\circ} \mathrm{C}\right)$ moist cure on Portland cement paste," Cement and Concrete Research, vol. 30, no. 12, pp. 1869-1877, 2000.

[13] G. Escadeillas, J.-E. Aubert, M. Segerer, and W. Prince, "Some factors affecting delayed ettringite formation in heat-cured mortars," Cement and Concrete Research, vol. 37, no. 10, pp. 1445-1452, 2007.

[14] K. Tosun, "Effect of $\mathrm{SO}_{3}$ content and fineness on the rate of delayed ettringite formation in heat cured Portland cement 
mortars," Cement and Concrete Composites, vol. 28, no. 9, pp. 761-772, 2006.

[15] R. Yang, C. D. Lawrence, C. J. Lynsdale, and J. H. Sharp, "Delayed ettringite formation in heat-cured Portland cement mortars," Cement and Concrete Research, vol. 29, no. 1, pp. 17-25, 1999.

[16] L. Lam, Y. L. Wong, and C. S. Poon, "Degree of hydration and gel/space ratio of high-volume fly ash/cement systems," Cement and Concrete Research, vol. 30, no. 5, pp. 747-756, 2000.

[17] C. S. Poon, L. Lam, and Y. L. Wong, "Study on high strength concrete prepared with large volumes of low calcium fly ash," Cement and Concrete Research, vol. 30, no. 3, pp. 447-455, 2000.

[18] C. C. Castellano, V. L. Bonavetti, H. A. Donza, and E. F. Irassar, "The effect of w/b and temperature on the hydration and strength of blastfurnace slag cements," Construction and Building Materials, vol. 111, pp. 679-688, 2016.

[19] K. Luke and F. P. Glasser, "Selective dissolution of hydrated blast furnace slag cements," Cement and Concrete Research, vol. 17, no. 2, pp. 273-282, 1987.

[20] B. A. Suprenant and G. Papadopoulos, "Selective dissolution of portland-fly-ash cements," Journal of Materials in Civil Engineering, vol. 3, no. 1, pp. 48-59, 1991.

[21] Q. Wang, M. Shi, and D. Wang, "Contributions of fly ash and ground granulated blast-furnace slag to the early hydration heat of composite binder at different curing temperatures," Advances in Cement Research, vol. 28, no. 5, pp. 320-327, 2016.

[22] T. Hemalatha and A. Ramaswamy, "A review on fly ash characteristics-towards promoting high volume utilization in developing sustainable concrete," Journal of Cleaner Production, vol. 147, pp. 546-559, 2017.

[23] F. U. A. Shaikh and S. W. M. Supit, "Compressive strength and durability of high-volume fly ash concrete reinforced with calcium carbonate nanoparticles," in Fillers and Reinforcements for Advanced Nanocomposites, chapter 11, pp. 275-307, Woodhead Publishing, 2015.

[24] A. M. Rashad, "A brief on high-volume Class F fly ash as cement replacement-a guide for Civil Engineer," International Journal of Sustainable Built Environment, vol. 4, no. 2, pp. 278-306, 2015.

[25] J. Liu, F. Xing, B. Dong, H. Ma, and D. Pan, "Study on water sorptivity of the surface layer of concrete," Materials and Structures, vol. 47, no. 11, pp. 1941-1951, 2014.

[26] H. Ma, Multi-scale modeling of the microstructure and transport properties of contemporary concrete [Ph.D. thesis], The Hong Kong University of Science and Technology, Hong Kong, 2013. 

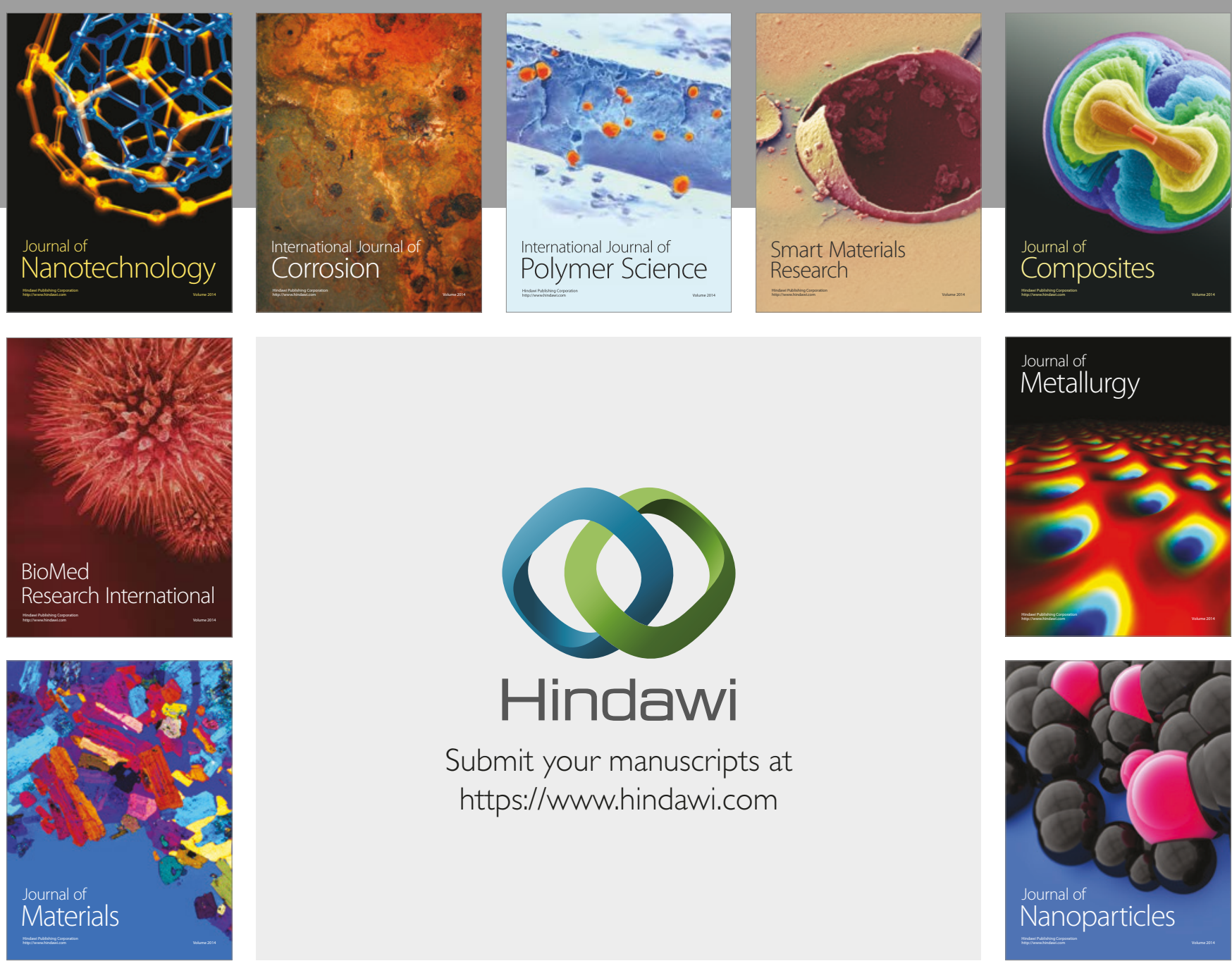

\section{Hindawi}

Submit your manuscripts at

https://www.hindawi.com
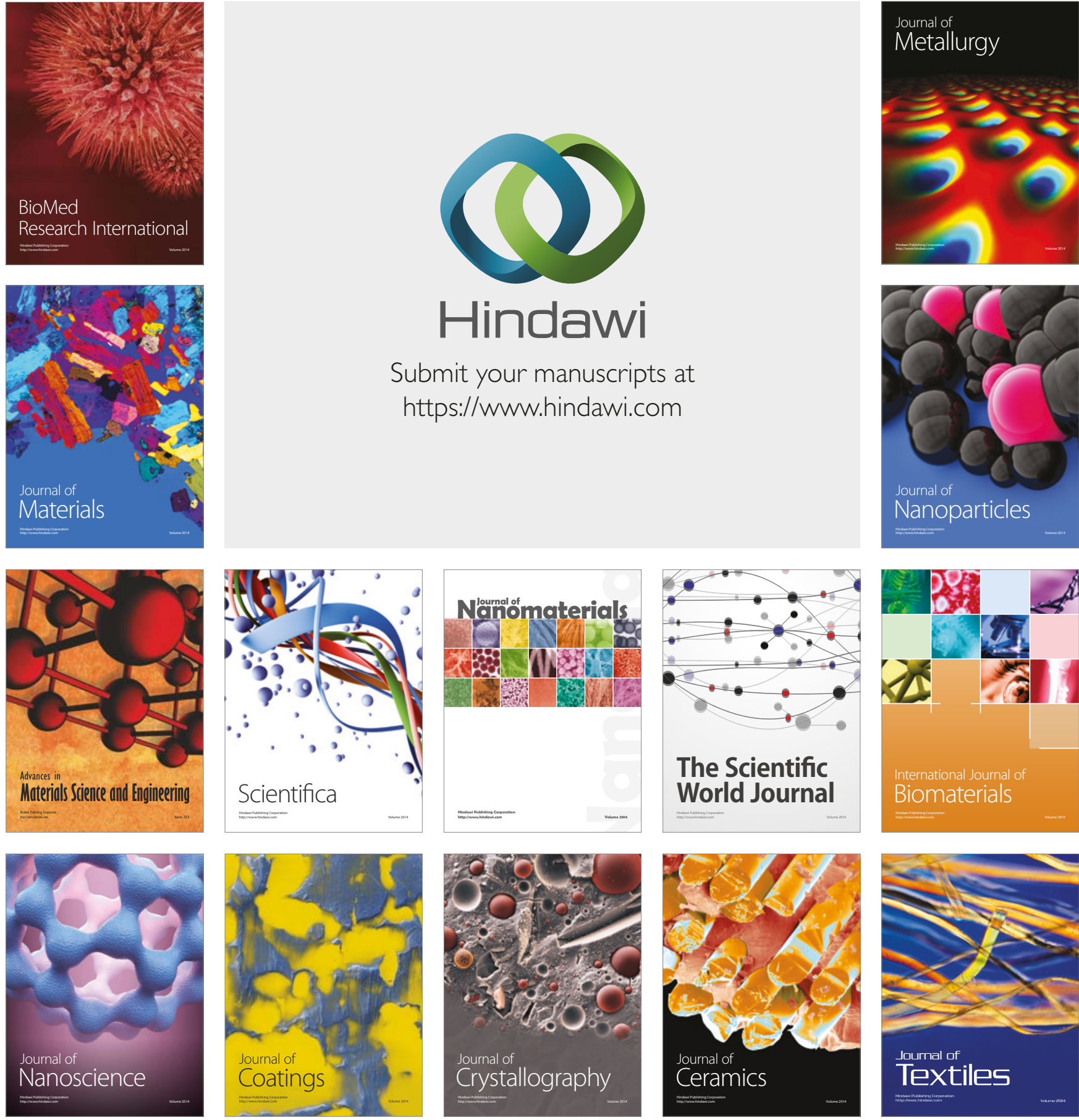

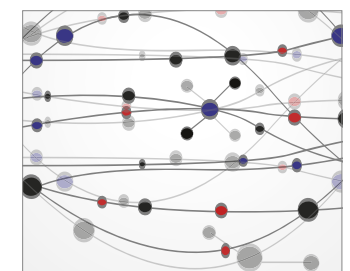

The Scientific World Journal
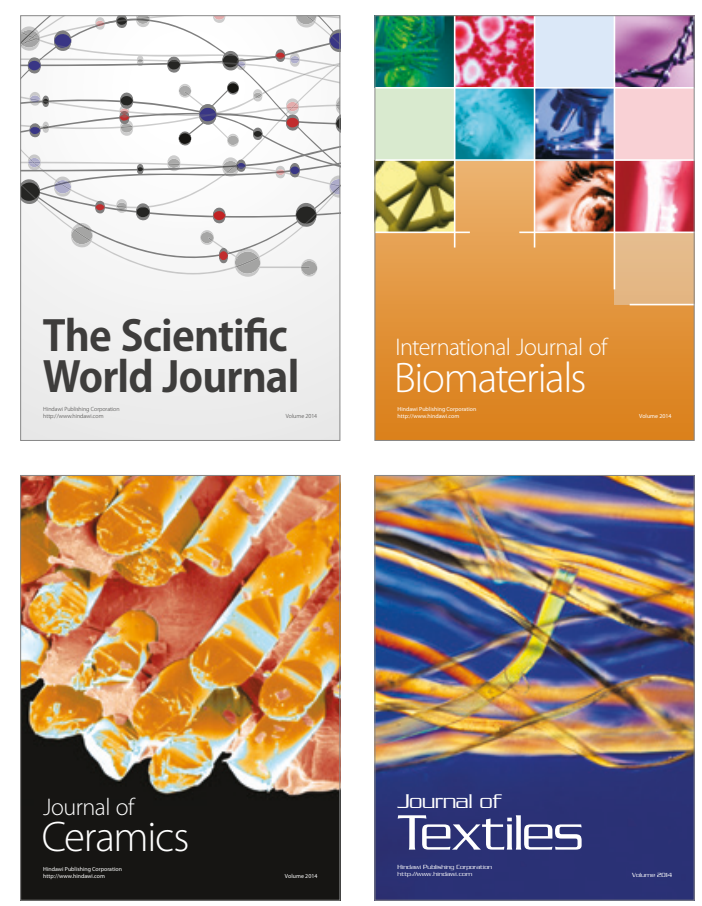